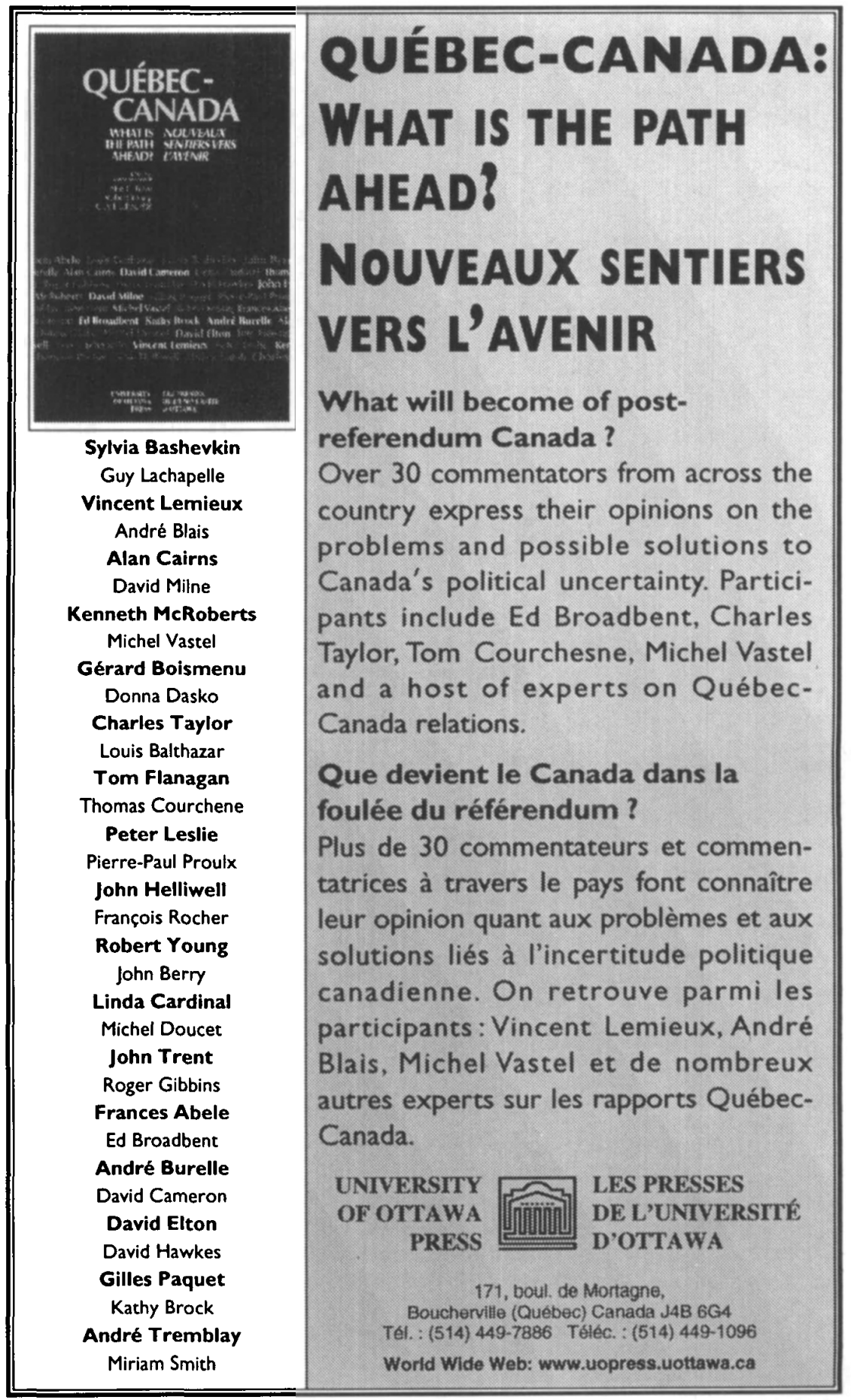




\section{Political Pundits}

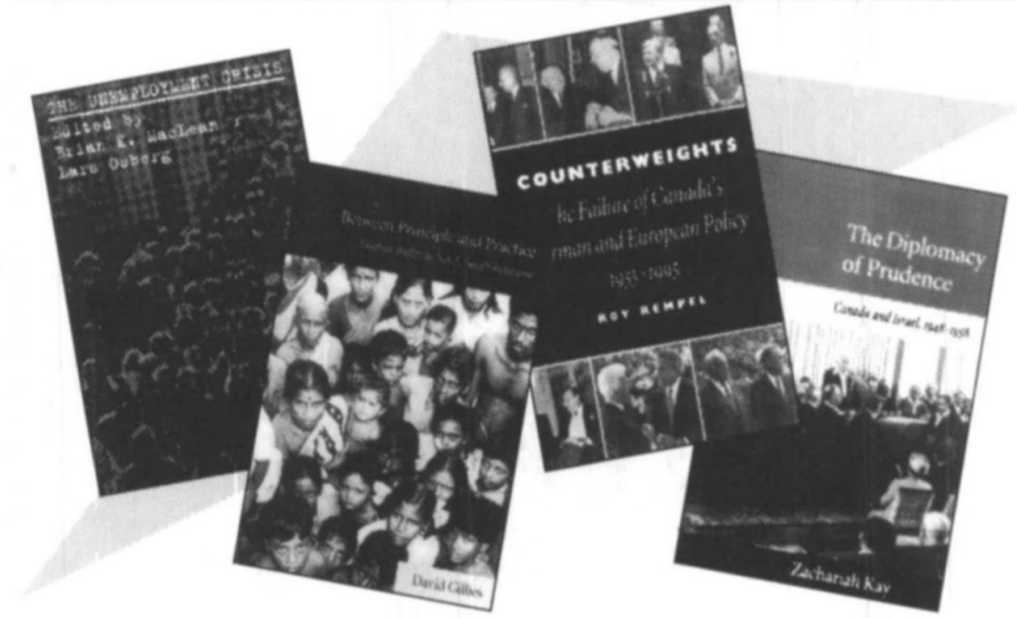

Understanding

Canada

Building on the New

Canadian Political

Economy

Edited by Wallace Clement

Paper $\quad 0-7735-1503-8 \quad \$ 22.95$

Cloth $\quad 0-7735-1502-X \quad \$ 55.00$
The Unemployment

Crisis

Edited by Brian $K$.

MacLean and Lars Osberg

Critical Perspectives on

Public Affairs

Paper 0-7735-1418.X \$22.95

Cloth $0-7735-1417-1 \quad \$ 55.00$
The Challenge of Direct Democracy The 1992 Canadian Referendum Richard Jobnston, André Blais, Elisabeth Gidengil, and Neil Nevitte

Paper 0.7735.1505.4 $\$ 19.95$

Cloth $\quad 0.7735 \cdot 1504-6 \quad \$ 44.95$

\section{Counterweights}

The Failure of Canada's

German and European

Policy, 1955-1995

Roy Rempel
The Diplomacy of Prudence

Canada and Israel, 1948-1958

Zachariab Kay
Between Principle and Practice

Human Rights in North-

South Relations

David Gillies

Paper $\quad 0-7735-1414-7 \quad \$ 22.95$

Cloth $0-7735-1507-0 \quad \$ 42.95$ Cloth $0.7735-1435-X \quad \$ 44.95$ Cloth $0.7735-1413.9 \$ \$ 55.00$

McGill-Queen's University Press

To order call toll-free: 1-800-565-9523

VISA/MasterCard/American Express accepted

Fax for USA and Canadian orders: 1-800-221-9985 


\section{AVIS}

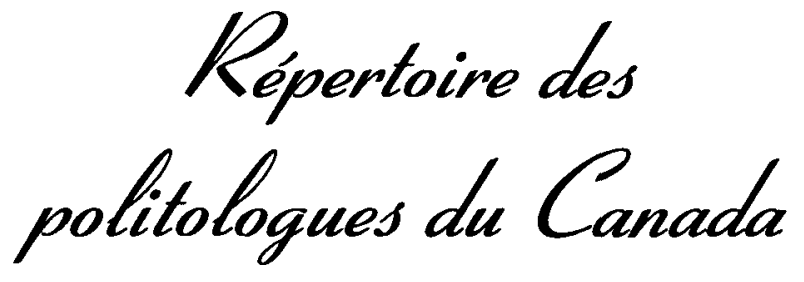

1996

\section{Maintenant disponible}

Le Répertoire des politologues du Canada, 1996 est maintenant disponible. Cette publication comprend une liste des noms et des données biographiques (incluant les domaines de spécialisation ainsi que les régions géographiques d'intérêt) des membres de l'ACSP/SQSP au $1^{\text {er }}$ octobre 1996, la liste des départements de science politique et la liste des programmes de $2^{e}$ et $3^{e}$ cycles.

PRIX UNITAIRE : $\quad 20 \$$ incluant la tps et les frais de manutention

\section{COMMANDES :}

Association canadienne de science politique

Bureau 205 - 1, rue Stewart

Université d'Ottawa

Ottawa, ON KIN $6 H 7$

(613) 564-4026

(613) 230-2746 (Télécopieur)

cpsa@csse.ca 


\section{NOTICE}

\section{Directory of Political Scientists in Canada}

\section{6}

\section{Now available}

The 1996 edition of the Directory of Political Scientists in Canada is now available. This publication includes the names and biographical information, including subject and geographical specializations, of the CPSA/SQSP members as of October 1, 1996, the list of departments of political science and the list of graduate programmes.

PRICE : $\quad \$ 20$ including GST and postage

\section{ORDERS:}

Canadian Political Science Association

Suite 205 - 1 Stewart Street

Ottawa, ON KIN $6 H 7$

(613) $564-4026$

(613) 230-2746 (Fax)

cpsa@csse.ca 


\section{Visit CJPS on the Internet at: / Visitez le site Internet de la Rcsp au:}

http://info.wlu.ca/ wwwpress/cjps.html

or at the CPSA site: / ou au site Internet de l'Acsp:

http://www.sfu.ca/igs/cpsa.html

\begin{tabular}{|c|c|c|c|}
\hline $\int_{U} \mid P S$ & $\begin{array}{l}\text { Canadian } \\
\text { Journal } \\
\text { of Political } \\
\text { Science }\end{array}$ & R Cop & $\begin{array}{l}\text { Revue } \\
\text { canadienne } \\
\text { de science } \\
\text { politique }\end{array}$ \\
\hline
\end{tabular}

\section{WELCOME / BIENVENUE}

Welcome to the homepage of the Canadian Journal of Political Science I

Bienvenue au réseau de l'information de la Revue canadienne de science politique.

(0) Canadian Political Science Association / Association canadienne de science politique

- General overview of CJPS / Un aperçu de la Rcsp

- Recent issues: tables of contents, article abstracts, lists of books reviewed / Numéros récents : sommaires, résumés des articles, listes de livres recensés

- About book reviews / Au sujet des recensions dans la Rcsp

- The cumulative index of CJPS / L'index des articles parus dans la Rcsp

- Submission of manuscripts / La soumission des manuscrits

- Subscription to CJPS / Adhésion à la Rscp

- Advertising Rates / Tarifs publicitaires 


\section{Notes to Contributors / Avis aux collaborateurs}

Authors are requested to forward four copies of their manuscripts together with four copies of an abstract of 100 words. Manuscripts should not be longer than 35 pages (all material included). All material, including footnotes, must be double-spaced. Tables and diagrams must be submitted on separate pages. In preparing a manuscript for consideration by the Editorial Board, authors should follow the JOURNAL's style sheet which the editors can supply. Otherwise, the most recent issue of the JourNaL can serve as a style guide. Manuscripts will not be returned. Authors may submit the final version on MS-DOS diskette in WordPerfect, Microsoft RTF or ASCII format, along with a hard copy of the file.

Les auteurs doivent faire parvenir en quatre exemplaires leurs manuscrits ainsi que leurs résumés de 100 mots. Les manuscrits ne doivent pas dépasser 35 pages dactylographiées à double interligne (y compris les notes, les références et les tableaux). Les tableaux et les graphiques doivent être soumis sur des pages séparées. Avant de soumettre un manuscrit, les auteurs doivent s'assurer que le protocole de rédaction de la REvuE est respecté. Ce protocole peut leur être envoyé sur demande ou ils peuvent s'inspirer à cet égard du dernier numéro de la REvuE. Les manuscrits ne sont pas retournés aux auteurs. Les auteurs peuvent soumettre leur version finale sur une disquette MS-DOS, en format WordPerfect, Microsoft R'TF ou ASCII, ainsi qu'une copie du texte imprimé.

The Editorial Board considers manuscripts on an exclusive basis only; that is, a manuscript submitted for consideration must not have been previously published, nor be under consideration, nor accepted for publication, elsewhere. The Board may judge manuscripts unsuitable if they are too narrow or specialized for an omnibus political science journal.

Le comité de rédaction considère que les manuscrits lui sont soumis en exclusivité; c'est-à-dire qu'un manuscrit soumis ne doit pas avoir déjà été publié, soumis ou accepté pour publication dans une autre revue. Le comité peut considérer inadmissibles des manuscrits portant sur des sujets trop spécialisés ou trop étroits.

Correspondence in English concerning manuscripts should be directed to Professor Christopher P. Manfredi, Department of Political Science, McGill University, Montréal, Québec H3A 2T7.

On doit adresser toute communication en français au sujet des manuscrits au Professeur François Rocher, Département de science politique, Carleton University, Ottawa, Ontario K1S 5B6.

INDEXED IN / INDEXÉE AU: International Political Science Abstracts/Documentation politique internationale; ABC POL SCI (Advance Bibliography of Contents: Political Science and Government); Historical Abstracts; America: History and Life; Political Science Abstracts; Point de Repère: index analytique d'articles de périodiques de langue française; Academic Abstracts; Social Science Source; Social Sciences Index; Sociological Abstracts (partial/partiel); United States Political Science Documents; Arts \& Humanities Citation Index (A\&HCl); Current Contents/Social and Behavioral Sciences; Social Sciences Citation Index; Social Scisearch; Research Alert; PAIS Bulletin and PAIS Foreign Language Index; Canadian Periodical Index/Index de périodiques canadiens; Canadian Magazine Index and available on-line in the Canadian Business and Current Affairs Database; Fachinformationsverbund, Internationale Beziehungen und Länderkunde, Freie Universität Berlin; Electoral Studies; Index to Canadian Legal Literature/Index à la documentation juridique au Canada (partial/partiel); Index to Canadian Legal Periodical Literature (partial/partiel); Indian Book Review Digest (partial/partiel); International Political Science Information Service; IBZ (Internationale Bibliographie der Zeitschriftenliteratur); IBR (Internationale Bibliographie der Rezensionen). 




